\title{
Efficacy of Lakshadi Plaster and Laksha Guggulu in the Management of Bhagna (Stable Colle's Fracture)
}

\section{Case Report}

\begin{tabular}{c}
\hline Dudhamal T $\mathbf{S}^{\mathbf{1}}$, Mahanta V $\mathbf{D}^{\mathbf{2}}$, Gupta $\mathbf{S ~ K}^{\mathbf{3}}$ \\
1,2. Assistant Professor, 3. Associate Professor \& HOD \\
Department of Shalyatantra, I.P.G.T. and R.A. \\
Gujarat Ayurved University, Jamnagar, Gujarat - 361 008, India. \\
\hline
\end{tabular}

\begin{abstract}
The application of lakshadi plaster in the cases of Bhagna (fracture) is an innovative idea in the form of Herbal plaster. In this case report single case was presented having the fracture of forearm i.e. colles' fracture. Laksha is a good bone healing so for the healing purpose internal Laksh Guggulu was given $1 \mathrm{gm}$ three times for one month. The final observation has shown that the Lakshadi Plaster achieve the aim of immobilization as effective as the POP (Plaster of Paris) without any complications. Internal Laksha Guggulu helps in early bone healing without any Calcium and Vitamins prescription.
\end{abstract}

Key words: Bhagna, Colles' Fracture, Lakshadi plaster, Plaster of Paris

\section{Introduction:}

In ancient classics there is very specific description of the Bhagna and their management. Sushruta has detailed the basic fundamental of the treatment of Bhagna which are adopted now days in the modern orthopedic practice as such.(1) In spite of all these reference in the Ayurveda the applied aspect of these principals are comparatively less. Sushruta mention 12 types of kandabhagna (fractures) and 6 types of Sandhimoksha (Dislocation and subluxations) in which he touches every kind of fracture without any radiological investigation.(2)

Colles' fracture is named after

*Corresponding Author:

\section{Dudhamal T. S.,}

Assistant Professor

Department of Shalyatantra,

I.P.G.T. and R.A.

Gujarat Ayurved University,

Jamnagar, Gujarat - 361 008, India.

Mob.09428671939

E-mail: drtsdudhamal@gmail.com
Abraham Colles, an Irish surgeon, who first described this condition. Colles' fracture is a broken radius bone in the arm near the wrist. It happens when a person slips or stumbles and puts out an open hand to break fall. Incidences are more in an older person whose bones are weakened and brittle mostly in menopausal women with osteoporosis. The symptoms may include sudden pain, bruising, swelling, disfigurement of the wrist (dinner fork deformity). The diagnosis was made by $\mathrm{X}$ Rays of the forearm and wrist. Stabilization of these fractures includes cast immobilization or surgical options like internal fixation, external fixation, percutaneous pinning, and bone substitutes.(3) A Colles' fracture usually takes up to 8 weeks to heal completely. XRays may be taken from time to time during recovery to see how it is healing. When the cast or splint is removed, the affected wrist and the fingers, hand, and shoulder on that side may be stiff for several weeks. So it requires exercise and physical therapy.(4) 
For immobilization of a fracture; cast application and POP is the most common method for fracture healing. Now-a-days synthetic casts are using which are stronger, lighter, more durable, radioluscent, and water resistant but more expensive than POP.(5) Due to POP complications like rashes, itching, dermatitis and cutaneous ulcerations may develops.(6) Limitations of POP are it has considerable weight and may lead to stiffness due to restricted movement in child. The setting of unmodified plaster starts about 10 minutes after mixing and is complete in about 45 minutes; however, the cast is not fully dry for 72 hours.(7) Recently water proof fiberglass casts adds approximately 2 to 3 more minutes to application time of the cast and increases the cost.(8)

Though there are many devices or material to immobilize the part the principle behind that is the same which Sushruta has mention for the treatment of fracture. So here an aim of immobilization has been fulfilled by using the herbal plaster i.e. Lakshadi plaster.

\section{Lakshadi Plaster:}

Lakshadi plaster was prepared from following ingredients which were used traditionally in Gujarat state for bone setting as well some drugs was having very good properties of bone healing as per Ayurvedic classic. For the purpose of immobilization Sushruta had mentioned the splints of different plants like Madhuk, Udumbar, Ashvatha etc which are tough in consistency.(9) He has also emphaszed principle of the rehabilitation after bhagna for normal functioning of the organ and fractured part.(10)

\section{Ingredients of Lakshadi plaster:}

1. Laksha (Resin of Laccita lacca)

2. Asthishrinkala (Cissus quadrangularis Linn.)
3. Multani Mitti earth)

4. Sudha Pashana (Talk Powder)

5. Guggulu (Commiphora mukul Engl.)

6. Kumari Ghana (Aloe vera Linn.)

\section{Preparation of Lakshadi Plaster (LP):}

All above ingredients of $L P$ were taken in powder form and in equal quantity (i.e. each $50 \mathrm{gms}$ ) then water is added to half of the total weight of dravyas. This mixture was then slowly heated up till the mixture boils. 2-3 cotton bandage rolls are soaked in this mixture and then LP roll is kept on the surface of the table for drying properly. Re-apply LP material over the bandage, after repeating this process 2-3 times. After drying up of roll, it was kept in plastic bags.

\section{Laksha Guggulu:}

Laksha Guggulu is indicated in the management of Bhagna as internal medicine in various texts. This compound preparation is comprised of six ingredients, and the details are available in Bhaishajya Ratnavali, Yogaratnakara, (12) \& Chakradatta (13) under the Bhagnadhikara. The Laksha Guggulu of $250 \mathrm{mg}$ prepared as per SOP of API and packed in polythene bag.

\section{Ingredients of Laksha Guggulu:}

1. Laksha: (Laccita lacca)-1 part

2. Asthishrinkhala: (Cissus quadrangularis Linn.) - 1 part

3. Kakubha: (Terminalia arjuna W. \&A.) - 1 part

4. Nagabala:(Grevia hirsuta Vahl.) - 1 part

5. Ashwagandha: (Withania somnifera (L.) Dunal) - 1 part

6. Shuddha Guggulu: (Commiphora mukul Engl.) - 5 part 


\section{Procedure of Lakshadi Plaster application:}

1. In this case; there was partial displacement of radial fracture, reduction was aimed for adequate opposition and normal alignment of bone fragments.

2. Reduction was achieved by Anchhana (traction) and Pidana (pressure) technique.

3. Cotton roll was applied below elbow up to metacarpal bone.

4. Lakshadi Plaster (LP) ingredients were boiled with water.

5. The bandages soaked with that Lakshadi material and then applied over the cotton roll maintaining the alignment of fractured fragments.

6. Total 4 bandages (4 inches size) of Lakshadi Plaster were applied and dried.

\section{Case Report}

A 70-year-old female patient of Kaph-Pittaja Prakriti presented to us for treatment of Colles' fracture having history of fall on left hand. She complained of pain, tenderness, and swelling on the left forearm. On examination redness in the form of ecchymosed and restricted movement of the wrist joint along with dinner fork deformity was noted. The x-ray of left wrist joint (AP view) showed the partial displaced fracture of lower end of the radius. [Figure-1]

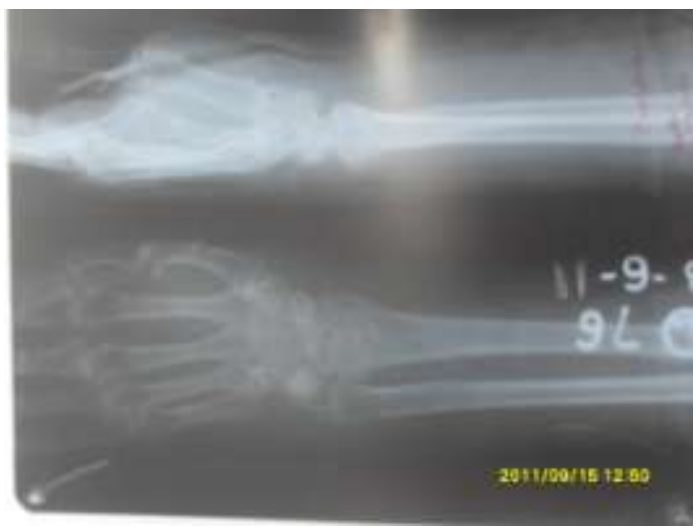

Legends:

Figure -1:

Left wrist X-ray of patient after $2^{\text {nd }}$ day of history of falling which shows fracture of lower end of radius with minimum displacement of fractured end.

All the routine laboratory investigations were within normal range. After confirmation of diagnosis on the basis of clinical and radiological findings; Lakshsadi plaster was applied below elbow joint and kept for 7 days. After 7 days again Lakshsadi plaster was reapplied when swelling was reduced. That Lakshsadi plaster was kept for 3 weeks which was in samabandha. (14) After 3 weeks plaster was removed and it was found that proper union of fracture bone in $\mathrm{X}$-ray. [Figure -2].

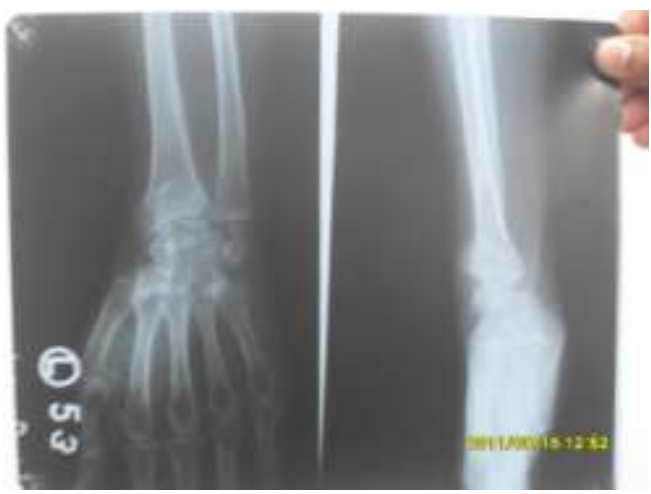

Legends:

Figure -2:

Left wrist X-ray of patient after Lakshadi Plaster application after 4 weeks which shows old fracture lower end of radius with good union.

Hence Lakshadi plaster was kept for total 4 weeks. Then patient underwent for murivenna abhyanga (Oliation) and parisheka (Pouring of oil) for 15 days. The plaster was not too tight so the patient was complete cured without any deformity or stiffness after one and half months. Laksha Guggulu, $250 \mathrm{mg} 4$ tablet thrice daily (1 $\mathrm{g}$ /day) with luke warm water after food for 30 days was prescribed. 


\section{Discussion:}

In Ayurveda the fracture and dislocation along with their treatment principle is described very beautifully which are adopted as such in today's practice. In above case the aim to treat fracture is immobilization of the fractured bone site. As there is availability of the POP for that purpose but being the Ayurved surgeon the aim is to treat fracture with Ayurved herbal plaster which has the same effect. So as per classics the drugs were selected which are bone healing and having the sticking property so the cast become hard. In this regard above Lakshadi plaster drugs almost have bone healing properties.

In this case the Lakshadi plaster was applied initially for one week and later on it was reapplied after it becomes loose due to reduction of the swelling. Hence immobilization of the forearm was done for 4 weeks. It was found that the plaster has expected hardness and weight is comparatively less than POP so patient felt good and the color of the plaster is brown similar to the skin color which is looking good. Hence an ultimate aim is to keep immobilization of the fracture part was achieved as such POP without any complications. Due to light weight stiffness of the wrist joint near to fracture site was minimal. The ingredients of the Lakshadi plaster might have some local effect on the site. Hence the same may be tried in significant number of patients for the concrete conclusion.

Laksha Guggulu was given $1 \mathrm{gm}$ three times a day internally with luke warm water for one month having the systemic effect for early healing. The details of probable mode of action of entire ingredients of Laksha Guggulu were given below.

\section{Discussion on probable mode of Action of Laksha Guggulu: \\ Guggulu:}

Guggulu has Shothahara (antiinflammatory) as well as Bhagna Sandhanakara (fracture healing) properties due to its anti-inflammatory $(15,16,17$, 18) effect. Experimental studies with Freundum resin extract of the oleo-gum resin reduced xylene-induced ear inflammation in mice by $50 \%$.

Laksha:

Laksha has properties like Bhagna sandhana (Bone healing), Vranaropaka (Wound healing), Rakta Stambhaka (Hemostasis). Experimental and histological study also showed that Laksha enhance the bone healing. (19)

\section{Ashwagandha:}

Ashwagandha constitutes the properties of Balya, Rasayana, Vedanasthapana anti-inflammatory, antioxidant, rejuvenating \& immunemodulator. (20)

Nagabala:

Nagabala is having Madhura, Kashaya Rasa, Guru, Snigdha and Pichchhila Guna, Shheta Veerya and Madhura Vipaka and Rasayana (21) properties.

Arjuna:

Arjuna having Raktastambhaka, Sandhaniya, Vranaropaka, Raktaprasadana properties. It is useful in fractures, ulcers, cardiac disorders, fatigue, intrinsic hemorrhages, tumor, inflammations, cirrhosis of liver and hypertension. (22)

Asthishrinkhala:

Asthishrinkhala has Sandhaniya, Dipana, Pachana, krimighna, RaktaStambhaka, Rakta Shodhaka karma so it is very useful in Asthibhanga, Abhighataja sotha and Raktasrava. Experimental and clinical studies reveal that Cissus quadrangularis Linn. is antioxidant (23) 
analgesic (24) anti-inflammatory (25) antipyretic, anti-microbial (26) activities. It contains natural steroids and vitamin (27) so it is very useful for early bone healing. $(28,29)$

So it can be said that Laksha Guggulu (30) has combined effects on bone healing without any multivitamins and calcium.

\section{Probable mode of action of Lakshadi Plaster:}

In this case Lakshadi Plaster was applied as a splint and the main ingredient is Laksha having Kashaya Rasa and Sheeta Veerya; which rendered soothing effect by virtue of its Vedanasthapaka (Pain-killer) and Shothagna (antiinflammatory) properties. Apart from that Lakshadi Plaster was proven as a good splint for immobilization and stabilization of fractured part which is necessary for healing of fracture. This all was probable due to sufficient hardness achieved after applying the plaster on fractured site.

\section{Merits of Lakshadi Plaster:}

$>$ Lakshadi Plaster is having light in weight when compared to Plaster of Paris cast and patient feels more comfortable with LP.

$>$ LP showed minimal side effects like, stiffness and restricted movement of the affected part due its herbal ingredients.

> LP provided Vedana shamaka (Pain-killer) and Shothaghna (Antiinflammatory) effects due to its ingredients, Guggulu, Kumari, Khatika having properties of reducing pain and inflammation.

$>$ LP having Sandhaniya (Healing) properties with Laksha, Asthishrinkhala, and Guggulu, which helped in healing of fractured bone quite early.

Demerits of Lakshadi Plaster:

$>$ LP required more time for setting and achieving hardness i.e. about 6 $-7 \mathrm{hrs}$.
LP is useful only in un-displaced, partial displaced and simple fracture for immobilization purpose.

\section{Conclusion:}

As this is a single case study, it can be conclude that in replace of POP we can use Lakshadi Plaster and Laksha Guggulu for immobilization and bone healing for Bhagna (un-displaced fracture)

\section{References:}

1. Yadavji Trikamji, Sushruta's Sushruta Samhita, Chikitsa Sthan 3/18-19; Reprint ed. Chaukhambha Orientalia,Varanasi. 2007. p. 416.

2. Yadavji Trikamji, Sushruta's Sushruta Samhita, Nidan Sthan 15/4; Reprint ed. Chaukhambha Orientalia,Varanasi. 2007. p. 328 .

3. William G Blakeney. Stabilization and treatment of Colles' fractures in elderly patients.

http://www.dovepress.com/articles.php?art icle_id=5677 dated 11.8.2011

4. Colles Fracture http://www.medindia.net/patients/patientin fo/colles-fracture.htm\# ixzz 1UkTswUPw download dated 12.08.2011.

5. Kowalski, Kurtis L "Evaluation of fiberglass versus plaster of Paris for immobilization of fractures on the arm and leg. Military Medicine. FindArticles.com. 10 Aug, 2011. http://findarticles.com/p/articles/mi qa391 2/is 200208/ai n9131512/

6. http://en.wikipedia.org/wiki/ Orthopedic cats downloaded date-10.8.2011

7. Schmidt V.E., Somerset J.H., Porter R.E. Mechanical Properties of Orthopedic Plaster Bandages. Journal of Biomechanics. 1973; (6); 173-185.

8. Salesnick H. "Waterproof Cast Liners Break Tradition" http://en.wikipedia.org/wiki/ orthopedic cats downloaded date-10.8.2011.

9. Yadavji Trikamji, Sushruta's Sushruta Samhita, Chikitsa Sthan 3/6; Reprint ed. Chaukhambha Orientalia,Varanasi. 2007. p. 415. 
10. Yadavji Trikamji, Sushruta's Sushruta Samhita, Chikitsa Sthan 3/35; Reprint ed. Chaukhambha Orientalia,Varanasi. 2007. p. 417.

11. Ambikadatta Shashtri, Bhaishajya Ratnavali,(Kanjiv lochan Eng Translation) Chap.49/14 reprint ed. Chaukhambha Sanskrita Sansthan, Varanasi, 2009 P. 775.

12. Laxmipatishashtri, Yogaratnakar, Uttarardha Laksha guggulu 11/1 Reprint ed. Chaukhambha Prakashan, Varanasi, Vi.S. 2067, p.191.

13. Sharma P.V. Chakradatta, Chap.49/12-13, first ed. Chaukhambha Orientalia, Varanasi, 2007, p. 386.

14. Yadavji Trikamji, Sushruta's Sushruta Samhita, Chikitsa Sthan 3/10; Reprint ed. Chaukhambha Orientalia,Varanasi. 2007. p. 415.

15. Sharma JN, Comparison of the AntiInflammatory activity of Commiphora mukul (An indigenous drug) with those of Phenylbutazone and Ibuprofen in experimental arthritis induced by Mycobacterial Adjuvant. Arzneimittelforschung, 1977; 27; p.14551457.

16. Arora RB et al. Anti-inflammatory studies on a crystalline steroid isolated from Commiphora mukul. Indian Journal of Medical Research. 1972; 60; p.929-931.

17. Duwiejua $M$ et al. Anti-Inflammatory Activity of Resins from Some Species of the Plant Family Burseraceae. Planta Medica. 1993; 59; p.12-16.

18. Atta AH, Alkofahi A. Anti-Nociceptive and Anti-Inflammatory Effects of Some Jordanian Medicinal Plant Extracts. Journal of Ethnopharmacology. 1998; 60; p.117-124

19. Deshpande P. J. Effect of Shell-lac in healing of fracture. Mechanics. March April,1999; 28(3-4);

20. Veena Sharma, Sadhana Sharma, Pracheta, Ritu Paliwal, Withania Somnifera: A Rejuvenating Ayurvedic Medicinal Herb for the Treatment of Various Human Ailments. International Journal of Pharmtech Research. Jan-Mar, 2011; 3 (1); p.187-192.

21. Sudip Kumar Rath, Ashashri Shinde, Pankaj Gahunge, Naresh Kumar Khemani,
Review of Antioxidant Activity of Rasayana Herbs Described in Ayurveda International Journal of Ayurvedic and Herbal Medicine. 2012; 2 (1); p. 202:217.

22. Kakubha- Data base on medicinal plant used in Ayurveda, CCRAS, Vol-3, p. 5762.

23. Garima Mishra, Saurabh Srivastava, B.P.Nagori, Pharmacological and Therapeutic Activity of Cissus quadrangularis: An Overview. International Journal of Pharmtech Research. April-June, 2010; 2 (2); p. 1298-1310.

24. Singh SP, Mishra N, Dixit KS, Singh N, Kohli RP: An experimentally study of analgesic activity of Cissus quadrangularis. Indian $\mathrm{J}$ of Pharmacol. 1984; 79; p. 162- 163.

25. Priyanka Vijay et al, Analgesic, AntiInflammatory and Antipyretic Activity of Cissus quadrangularis. Journal of Pharmaceutical Science and Technology. 2010; 2 (1); p. 111-118..

26. Alcoholic extract of the stem showed activity against Escherichia coli. With India- Raw Materials, II, 184; Fl Br Ind, I, p. 645 .

27. Justin Raj S., Baby Joseph, Pharmacognostic and traditional properties of Cissus quadrancularis Linn -An overview. International Journal of Pharma and Bio Sciences. Jan-Mar, 2011; 2 (1); p.131-139.

28. Udupa K. N. and Guru Charan Prasad, Further Studies on the Effect of Cissus quadrangularis in Accelerating Fracture Healing. Ind. Jour. Med. Res. Jan, 1964; 52(1); p.26-35.

29. Deka D.K., Lahon L.C. ,Saikia J., Mukit A. Effect of Cissus quadrangular/s in accelerating healing Process of experimentally fractured radius-ulna of dog: A preliminary study. Indian Journal of Pharmacology. 1994; 26; p. 44-45.

30. Kshipra Rajora, Sarvesh Kumar Singh, R.S. Sharma, S.N Sharma, Clinical Study on Laksha Guggulu, Snehana, Swedana and Traction in osteoarthritis. AYU. 2010; 31 (1) p.80.87. 